\title{
Water Resources Issues in Tarkwa Municipality, Southwest Ghana*
}

\author{
J. S. Kuma and A. Ewusi
}

Kuma, J. S. and Ewusi, A., (2009), "Water Resources Issues in Tarkwa Municipality, Southwest Ghana”, Ghana Mining Journal, Vol. 11, pp. 37 - 46.

\begin{abstract}
Tarkwa is an old and important gold mining town located in a sub-humid tropical climate with its economy built on mining and allied services. The current high gold price has generated a vibrant local economy in Tarkwa and increased its population and water use. Consequently, the water resources of Tarkwa are getting under pressure. Data on the annual ratio of water produced by Ghana Water Company Limited (GWCL) at the Bonsa Treatment Plant (BTP) to population growth of Tarkwa from 1987 to 2008 reveal an amount of 76 litres/person/day in 1987 decreasing to 40 litres/person/day in 2008. These figures show that the amount of water produced over the years has not kept pace with population growth in Tarkwa.

Additionally, Unaccounted For Water (UFW) is very high, although it is gradually being reduced from 66 \% in 1991 to 34 $\%$ in 2007. As a result of the inadequate water provided by GWCL, more than 318 wells have been constructed in Tarkwa. However, most of the wells were constructed without recourse to professional advice and preliminary results have revealed that some are biologically and chemically contaminated while others are at risk of becoming contaminated. Additionally, inadequate waste disposal practices, building on hills and in recharge areas, washing of cars into receiving streams, illegal mining and its processing also into receiving streams suggest that surface and some ground water are being contaminated. A comprehensive water resources management plan in the form of an environmental impact statement including the delineation of groundwater protection zones is recommended to address water issues in Tarkwa. Public education on environmental issues, enactment and enforcement of by-laws arising from this plan should be implemented.
\end{abstract}

\section{Introduction}

Tarkwa has been an important gold trading centre with the Europeans since the fifteenth century and according to Junner (1935), Collings was the first to write a report about the gold fields around the Tarkwa area in 1909. Several small and large mine holdings have existed until the Second World War forced many of these mines to close down, resulting in a decline in minerals production in the then Gold Coast (now Ghana). An upsurge in economic activity after the war enabled minerals production to increase. However, during the 1970's a steady decline in the minerals industry again occurred until a revitalisation plan was worked out by the Government of Ghana with the help of external financial institutions such as the International Monetary Fund (IMF) and the World Bank in the mid 1980's (Sraku-Lartey 1993). The result was that Ghana produced more than $78000 \mathrm{kgs}$ (2.5 million ounces) of gold at the height of the third gold boom in 1998, representing $90 \%$ of mineral exports, which accounted for more than $40 \%$ of the country's foreign exchange earnings.

The economy of Tarkwa has directly benefited from the intensive mineral exploration and mining activities, leading to the establishment of three large-scale surface mines and several allied servicing companies. The large-scale surface operations are located within a radius of about $7 \mathrm{~km}$ of Tarkwa, namely AngloGold-Ashanti Iduapriem Limited (AAIL), Goldfields Ghana Limited (GGL) and Ghana Manganese Company Limited (GMCL) (Fig. 1). The current high gold price has boosted mineral exploration, and has led to the establishment of new mines and expansion programmes in old mines in many parts of Ghana. For example, GGL has been investing about US\$200 million since 2003. Also within the last decade, six new high profile commercial banks have been established in Tarkwa in addition to the four already existing ones and two rural banks.

The 2000 national population and housing census of Ghana revealed that the population of Tarkwa municipality (including its immediate satellite communities e.g. Akyempim, Nsuta, Kwabedu, New Atuabo, Akoon, Essamang Kakraba), hereafter called Tarkwa was 68946 although in 1984, it was 22 107. With a population growth of about 3.1 $\%$ per year and a vibrant mineral driven economy, which has attracted many people to migrate, an estimate of Tarkwa's current population is 90000 . The positive correlation between population growth and water demand is well established (Kulshreshtha, 1998; Hiscock et al, 2002). The

* Manuscript received January 04, 2009

Revised version accepted October 10, 2009 


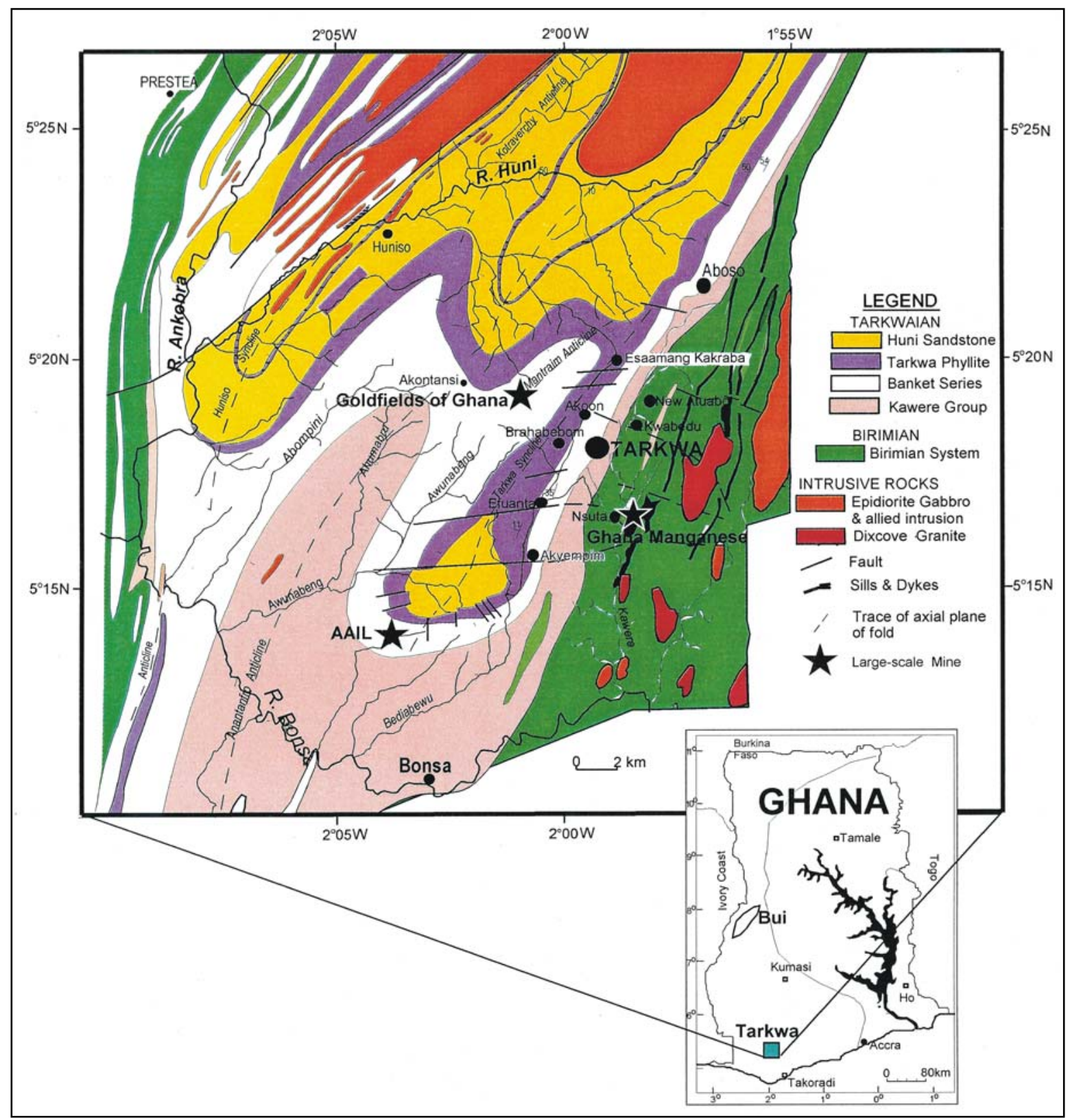

Fig. 1 Simplified Geological Map of the Tarkwa Area (Modified from Junner et al, 1942)

importance of gold mining to the local economy of Tarkwa and thus, the national economy of Ghana means that water management issues in the municipality need to be examined. The impacts of mining on surface and ground water quality and quantity around the Tarkwa area have been well documented (Kuma and Younger, 2001; Kortatsi, 2006; Kuma and Younger, 2004 and Kuma, 2004). However, detailed appraisal of the water situation within Tarkwa itself has not been undertaken. The objective of this paper is to bring to the fore how intensified mining activities, increase in population and society's behavioural patterns are impacting the water resources in Tarkwa. Mechanisms necessary to address these issues are discussed.

\section{Physiography}

Tarkwa lies within the transition zone between the Rain Forest and Moist Semi-deciduous Forest of Ghana in the Ankobra River basin and experiences a double maxima annual rainfall regime with the major maximum from the end of April to July and the minor through September to November (Figure 2; Dickson and Benneh, 1995). Rainfall figures from 1939 to 2008 reveal an annual mean of 1900 $\mathrm{mm} / \mathrm{yr}$. The lowest and highest rainfall years are 2000 and 1995 respectively with $1140 \mathrm{~mm}$ and 2 $980 \mathrm{~mm}$. Fig. 2 also shows monthly minimum, mean and maximum rainfall values where four months (January, February, August and December) 
did not record any rainfall while the highest rainfall of $810 \mathrm{~mm}$ was recorded in June. Using the average monthly rainfall figures for Tarkwa from 1939 to date as input to the hydrological classification by Chang and Lau (1993) showed that Tarkwa experiences 8 wet months and 4 dry months (of which 2 are semi-wet), representing a sub-humid tropical climate. Average monthly temperatures and relative humidities are between $28-33^{\circ} \mathrm{C}$ and 83 - $91 \%$ respectively.

Relief is moderate in Tarkwa and the district i.e., between $50 \mathrm{~m}$ and $230 \mathrm{~m}$ (above mean sea level) and decreases to the south. The terrain is characterised with a series of parallel ridges (composed of Banket Series and Tarkwa Phyllite rocks) and valleys oriented along the general NE-SW trend of the rocks which are attributed to pitching fold and dip-and-scarp slopes expressed over the landscape (Whitelaw, 1929). Local flow systems are therefore expected as water would move from a recharge area to the next adjacent discharge area. The drainage pattern in the district is dendritic, bordered to the west by the southerly flowing Ankobra River. The Huni and Bonsa Rivers both flow in westerly directions and respectively demarcate the northern and southern extremities of a $400 \mathrm{~km}^{2}$ area (Fig. 1). These rivers are perennial even though during dry months their flows decrease significantly. There are several tributaries to the rivers: the main ones are the Awunabeng, Essumang, Bediabewu, Abompini and Kawere.

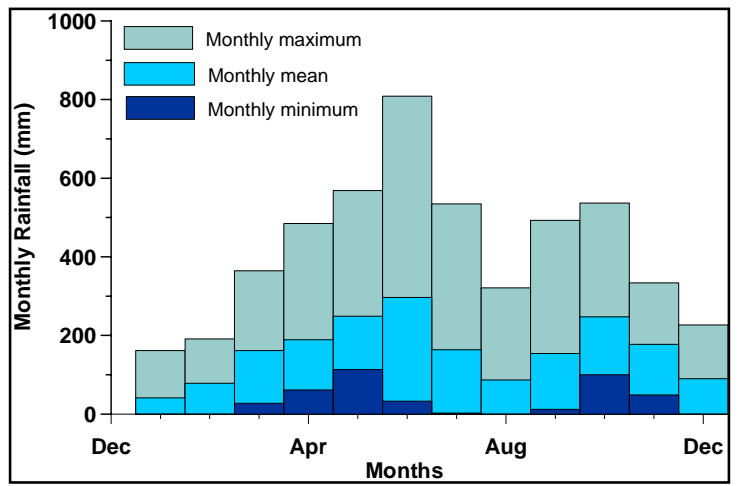

Fig. 2 Precipitation in Tarkwa from 1939 to 2008

\section{Litho- and Hydro- Stratigraphy}

Tarkwa is located on the contact between Tarkwaian rocks due west and older Birimian Supergroup of Ghana to the east (Fig. 1). Tarkwaian rocks have been studied hydrogeologically more than the adjoining Birimian rocks due to the presence of gold in the Tarkwaian even though manganese is hosted in the Birimian meta volcanics near Nsuta.
The Birimian Supergroup consists of penecontemporaneous low-grade metamorphosed sedimentary and volcano-clastic rocks (Eisenlohr and Hirdes, 1992). In the Tarkwa area the rocks consist of phyllites and pyroclastics made of tuffs with interbedded mudstones which are intruded by andesitic and basaltic lavas. The metamorphosed rocks are tightly folded and fractured with a weathering profile of more than $100 \mathrm{~m}$ in some places (Junner et al. 1942). Secondary porosity due mainly to weathering is expected to be more important than primary porosity in the formation of aquifers in the Birimian.

The Tarkwaian, considered as a molassic facies derived from the Birimian rocks consists in general, of coarse, poorly sorted, immature sediments with low roundness (Junner et al. 1942; Fig. 1). The sediments have been metamorphosed to lowgrade greenschist facies and are commensurate with a braided stream environment (Kesse, 1985). The Tarkwaian consists of the Kawere Group, Banket Series (host of gold ore), Tarkwa Phyllite and Huni Sandstone (actually quartzite) in order of decreasing age. Fault and joint density is quite high. The dominant joint directions are ESEWNW, although NW-SE and N-S trends are also present. Both strike- and dip-parallel faults are present: the former occur as upthrusts and are closely associated with folds while the latter reveal themselves as breaks in the topography (Hirdes and Nunoo, 1994). The weathering profile of Tarkwaian rocks average $20 \mathrm{~m}$. Groundwater is mainly hosted in the soft and easily weathered grits of the Banket and fracture zones within the Tarkwaian, especially in the phyllites.

Groundwater recharge and actual evapotranspiration have been estimated at between 11-17 \% and $54 \%$ respectively of annual rainfall (Kuma, 2007). The moderate relief of Tarkwa coupled with both relatively high rainfall and actual evapotranspiration in addition to low groundwater recharge, confirm the relatively high runoff experienced by her rivers and streams. The most important aquifers in both Birimian and Tarkwaian rocks are expected to be associated with secondary porosity, hosted in the regolith.

\section{Water Production and Supply Issues}

The main source of water supplied by Ghana Water Company Limited (GWCL) to communities is obtained from the Bonsa River, treated at BTP, pumped a distance of $15 \mathrm{~km}$ to Tarkwa and distributed. Water production data obtained from GWCL for BTP spanning 1987 to 2008 was compiled and is presented in Fig. 3. The trend observed depicts two blocks; that is 1987-1993 and 1994-2008. 


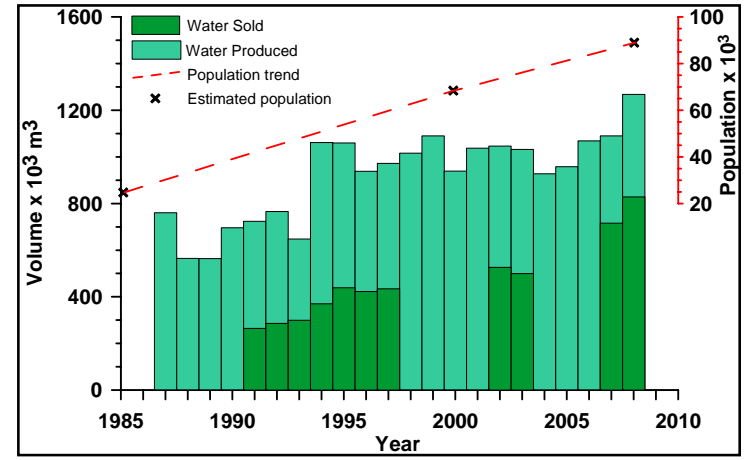

Fig. 3 Population Growth Trend and Annual Volumes of Water Produced and Sold by GWCL in Tarkwa

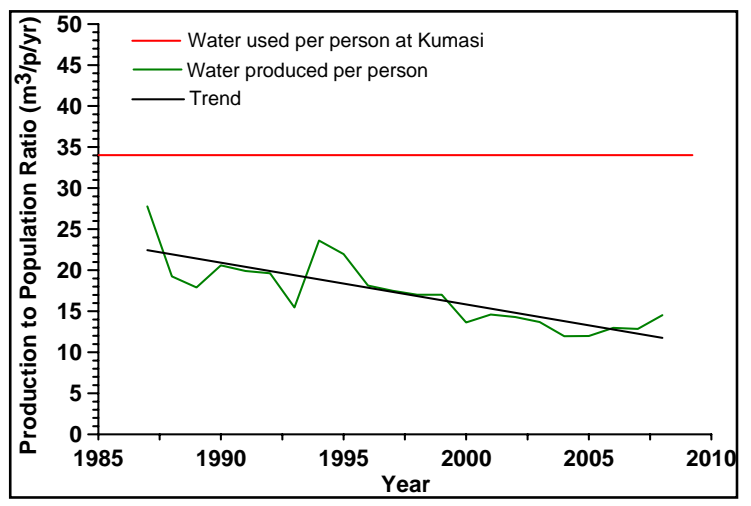

Fig. 4 Ratio of Water Produced to Population in Relation to Water Required

The mean values for the first and second blocks are $673000 \mathrm{~m}^{3}$ and $1022000 \mathrm{~m}^{3}$ respectively, revealing a significant increase in water production: a direct result of the establishment of the defunct Teberebie Goldfields Limited and AAIL (formerly Ghana Australian Goldfields) who started pouring gold in 1991 and 1992 respectively. These two gold mines directly and indirectly attracted many people to Tarkwa mainly for economic reasons and GWCL had to respond to water population demand. Indeed, 1994-1999 represent the peak period of the third gold boom in Ghana. It should be noted however that water produced by GWCL is not used for gold production.

Although water production fell slightly between 2000 and 2005 compared to 1994-1999, production between 1994 and 2007 can be described as relatively stable. The significant water produced in 2008 may be attributed to better managerial controls. While the volume of water produced from 1987 to 2008 increased by $77 \%$, the population of Tarkwa increased by $290 \%$ during the same period suggesting that water produced has not kept pace with population growth and therefore is inadequate. A recent study on the Bonsa River sug- gests that more treated water can be produced (Antwi, 2007).

Available annual figures of metered water sold by GWCL during the period between 1991-1997, 2002-2003, and 2007-2008 are also plotted in Figure 3. It is observed that the amount of water actually sold to customers annually compared to the water produced range from 35 to $66 \%$. Unaccounted For Water (UFW) is 'the difference between the amount of water a utility purchases or produces and the amount of water that it can account for in sales and other known uses for a given period' (Yepes and Dianderas, 1996). UFW are revenue losses to GWCL and the main causes are due to illegal connections, pipe leaks and busts which represent 34-65 \% of water produced. Thackery (1992) suggests UFW of up to $25 \%$ for utility companies. Fig. 3 shows that there has been a consistent reduction in UFW between 1991 and 2008; to $34 \%$ in 2007 . The ratio of annual water produced to population is plotted in Fig. 4 and the trend observed is decreasing water availability at a rate of $0.51 \mathrm{~m}^{3} / \mathrm{yr}$. A study conducted in four major suburbs in Kumasi by Adusei (2003) revealed that average domestic per capita water consumption was $34.3 \mathrm{~m}^{3} / \mathrm{yr}$ (94 litres/day). If this amount is used as a reference and compared to Tarkwa, assuming all water produced is available for consumption, it is observed that $81 \%$ or 76 litres/day was produced per person in 1987 decreasing to 42 $\%$ (40 litres/day) in 2008. These figures show that the amount of water produced by GWCL has not been commensurate with population growth and is inadequate.

To augment the shortfall in pipe-borne water from BTP many individuals and a few communities have constructed wells. Groundwater is tapped mainly in the regolith with a maximum depth of wells generally less than $20 \mathrm{~m}$. During the study an inventory undertaken in Tarkwa revealed more than 318 wells; out of which 294 are privately owned open-top hand dug wells (Fig. 5a) and 24 are mechanised. However, 177 are used by the community and the rest privately. 136 are used for drinking while the rest are for other purposes. Only 24 of the wells have been chemically and biologically analysed and 14 have been abandoned. 22 wells dry-up during the dry season probably because they are not deep enough or more water is withdrawn than is able to recharge them. 28 wells overflow in the rainy season due to the fact that they are located in discharge zones and are deep enough for their water head to be higher than the ground surface. Community based wells in use are well-patronised especially in areas without pipe borne water or when normal water supply from the BTP becomes irregular (Fig. 5b). Additionally, the prevailing price of treated water has affected 


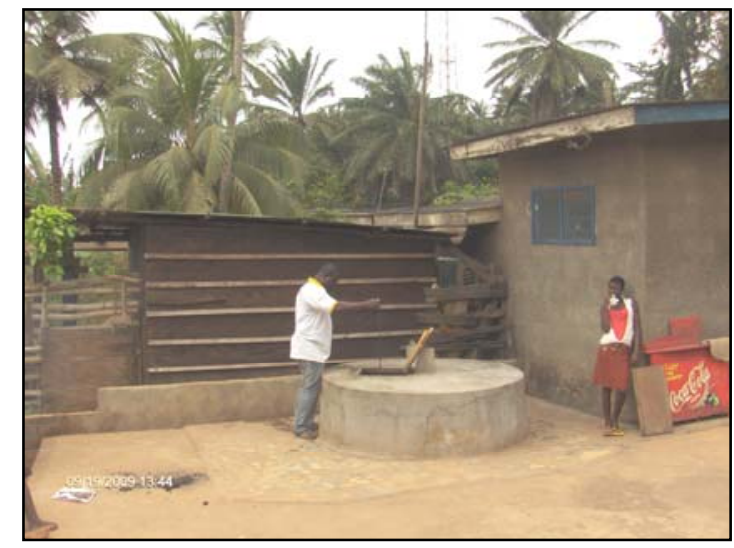

Fig. 5a Typical Open Top Hand Dug Well with Clean Surrounding

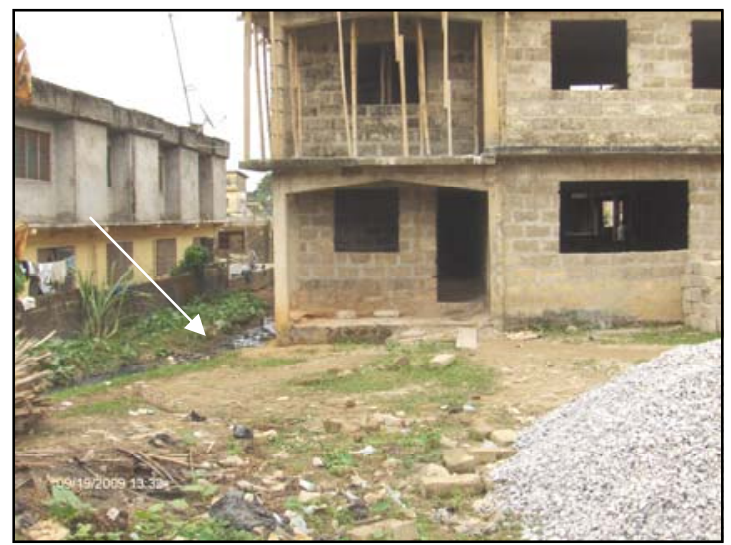

Fig. 5c A Heavily Polluted Stream (arrowed) very close to the Building to the right

some households such that they use the well water as a cheaper alternative or for some particular chores, e.g. washing. It is estimated that $30 \%$ of all water used come from groundwater.

\section{Water Quality Issues}

The raw water treated by GWCL at the BTP is of remarkably good quality perhaps because the Bonsa River flows east of Tarkwa and away from both large- and small-scale gold mines. Table 1 shows annual minimum and maximum values of raw water analysed from Bonsa River between 2005 and 2008. The maximum values recorded for turbidity, colour and suspended solids are for the rainy seasons when runoff to the River is high. Maximum ions concentrations were recorded during low flow.

More than $80 \%$ of the wells in Tarkwa have been sited and constructed by individuals without the

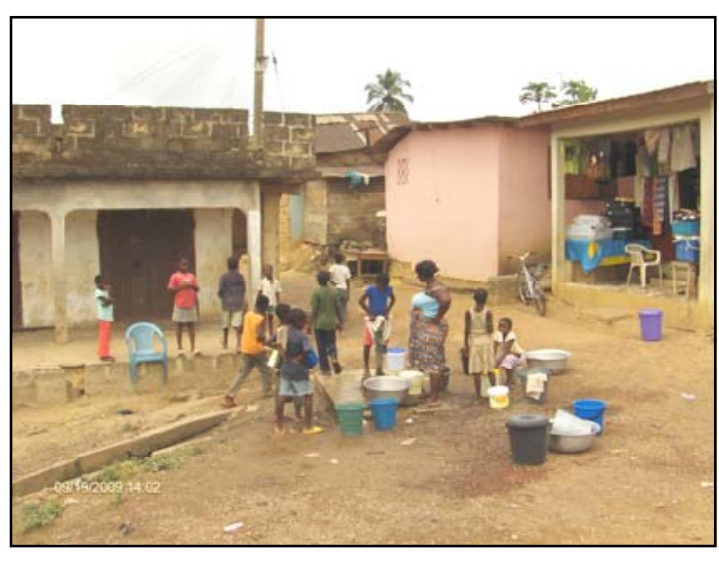

Fig. 5b Community Based Hand-Pump Wells

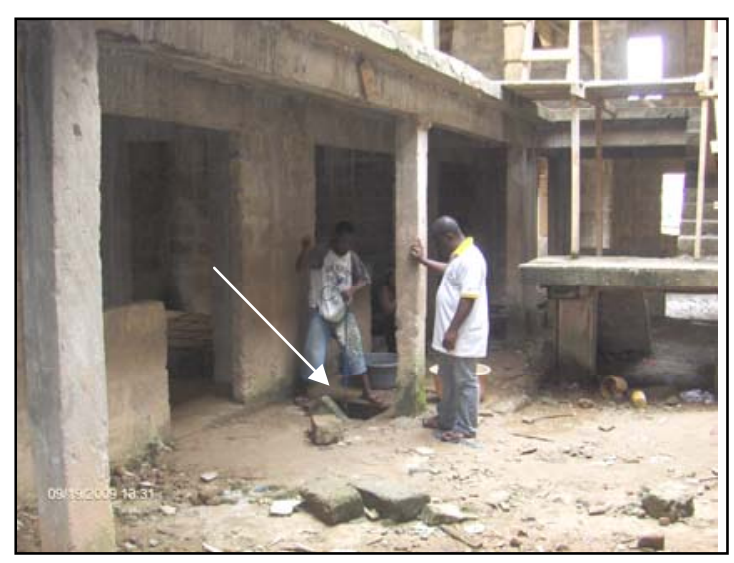

Fig. 5d Within the Compound of the house mentioned in Fig. 5c is a Well (arrowed)

involvement of professional advice. 208 of these wells are located in groundwater discharge areas (Fig. 5c-e) and the colour of water in 108 becomes brownish during rainy seasons suggesting that they have been contaminated. 43 wells are either less than $20 \mathrm{~m}$ from rubbish dumps and septic tanks or are located down-gradient of them, rendering them prone to contamination. Indeed, preliminary studies on five wells suspected to be contaminated showed that they all had high levels of faecal coliform ranging from $8-12 \mathrm{cfu} / 100 \mathrm{ml}$ (Adams, 2007).

\section{Social Issues Affecting Water Quality and Quantity}

Tarkwa enjoys significant population growth and economic development because of mining activities. Migration of unskilled youth into Tarkwa looking for mining jobs that are available for pro- 
Table 1 Annual Minimum and Maximum Raw Water Quality from Bonsa River before Treatment Compared with EPA General Effluent Guidelines for Discharges into Water Bodies (Anon, 1990)

\begin{tabular}{|c|c|c|c|c|c|c|c|c|c|c|}
\hline \multirow{3}{*}{ Parameters } & \multirow{3}{*}{ Units } & \multicolumn{8}{|c|}{ Years } & \multirow{3}{*}{ EPA } \\
\hline & & \multicolumn{2}{|c|}{2005} & \multicolumn{2}{|c|}{2006} & \multicolumn{2}{|c|}{2007} & \multicolumn{2}{|c|}{2008} & \\
\hline & & Min & Max & Min & Max & Min & Max & Min & Max & \\
\hline TEMPERATURE & ${ }^{\circ} \mathrm{C}$ & 22.9 & 25.9 & 20.7 & 25.8 & 19.4 & 28.9 & 18 & 27.6 & $<3^{0} \mathrm{C}$ aa \\
\hline Turbidity & NTU & 5 & 50.3 & 7.8 & 32.5 & 0.2 & 28.52 & 6.5 & 54.8 & 75 \\
\hline $\mathrm{pH}$ & & 4.3 & 7.5 & 6.1 & 7.7 & 6.2 & 7.5 & 6.1 & 7 & $6-9$ \\
\hline Colour & PtCo & 25 & 399 & 30 & 260 & 82 & 262 & 46 & 380 & 200 \\
\hline Conductivity & $\mu \mathrm{s} / \mathrm{cm}$ & 59 & 516 & 51.6 & 114 & 50 & 106 & 45.1 & 146 & 1500 \\
\hline TDS & $\mathrm{mg} / \mathrm{l}$ & 24 & 206 & 21 & 46 & 18 & 44 & 22 & 92.3 & 1000 \\
\hline Total Hardness & $\mathrm{mg} / \mathrm{l}$ & 13 & 60 & 16 & 59 & 6 & 74 & 16 & 116 & 500 \\
\hline Total Alkalinity & $\mathrm{mg} / \mathrm{l}$ & 20 & 45 & 18 & 52 & 23 & 60 & 24 & 82 & 200 \\
\hline Suspended solids & $\mathrm{mg} / \mathrm{l}$ & - & - & - & - & - & - & 8 & 30 & 50 \\
\hline Free CO2 & $\mathrm{mg} / \mathrm{l}$ & 0.06 & 7 & 5 & 61 & 4 & 50 & 4 & 38 & 10 \\
\hline Nitrate & $\mathrm{mg} / \mathrm{l}$ & 0.7 & 7.2 & 0 & 3.6 & 0 & 3.6 & 0.01 & 5.9 & 50 \\
\hline Nitrite & $\mathrm{mg} / \mathrm{l}$ & 0.004 & 0.5 & 0 & 3 & 0 & 0.033 & 0 & 9 & 50 \\
\hline Chloride & $\mathrm{mg} / \mathrm{l}$ & 0.62 & 101 & 10 & 114.5 & 10 & 16 & 5 & 230 & 250 \\
\hline Sulphate & $\mathrm{mg} / \mathrm{l}$ & 1 & 210 & 0 & 19 & 0 & 17 & 8 & 25 & 300 \\
\hline Total iron & $\mathrm{mg} / \mathrm{l}$ & 1.09 & 2.38 & 0.1 & 1.72 & 0.64 & 1.45 & 0.24 & 2.65 & 1 \\
\hline Manganese & $\mathrm{mg} / \mathrm{l}$ & 0.011 & 4.8 & 0.014 & 1.5 & 0.012 & 0.63 & 0.02 & 0.25 & 0.1 \\
\hline Ammonia (N) & $\mathrm{mg} / \mathrm{l}$ & - & - & 0.16 & 0.63 & 0.1 & 1.45 & 0 & 4.56 & 1.0 \\
\hline Calcium & $\mathrm{mg} / \mathrm{l}$ & - & - & - & - & - & - & 5 & 22.4 & - \\
\hline Magnesium & $\mathrm{mg} / \mathrm{l}$ & - & - & - & - & - & - & 2 & 3.4 & - \\
\hline Phosphate & $\mathrm{mg} / \mathrm{l}$ & - & - & 0 & 0 & 0 & 5 & 0.01 & 5.3 & 2 \\
\hline Copper & $\mathrm{mg} / \mathrm{l}$ & - & - & 0 & 0 & 0 & 0.19 & 0 & 0.79 & 2.5 \\
\hline Fluoride & $\mathrm{mg} / \mathrm{l}$ & - & - & - & - & - & - & 0 & 0.81 & 10 \\
\hline Aluminium & $\mathrm{mg} / \mathrm{l}$ & - & - & - & - & - & - & 0 & 0.02 & 5 \\
\hline Dissolved Oxygen & $\mathrm{mg} / \mathrm{l}$ & - & - & 5 & 5.8 & 3.96 & 8.8 & 6.2 & 8.3 & $>5$ \\
\hline Zinc & $\mathrm{mg} / \mathrm{l}$ & - & - & - & - & - & - & 0 & 0.02 & 5 \\
\hline Lead & $\mathrm{mg} / \mathrm{l}$ & - & - & - & - & - & - & 0 & 0 & 0.1 \\
\hline Chromium & $\mathrm{mg} / \mathrm{l}$ & - & - & - & - & - & - & 0 & 0.02 & 0.1 \\
\hline
\end{tabular}

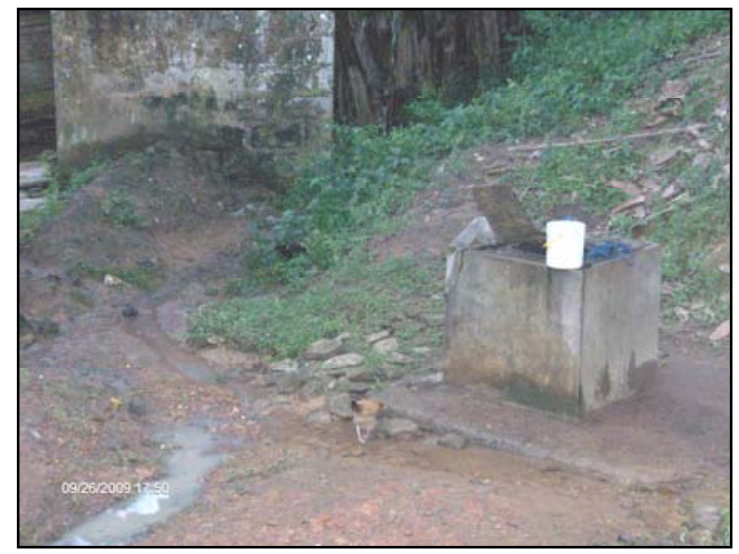

Fig. 5e Open Top Hand Dug Well located on a Spring Line but with Polluted Water Flowing about $2 \mathrm{~m}$ from it

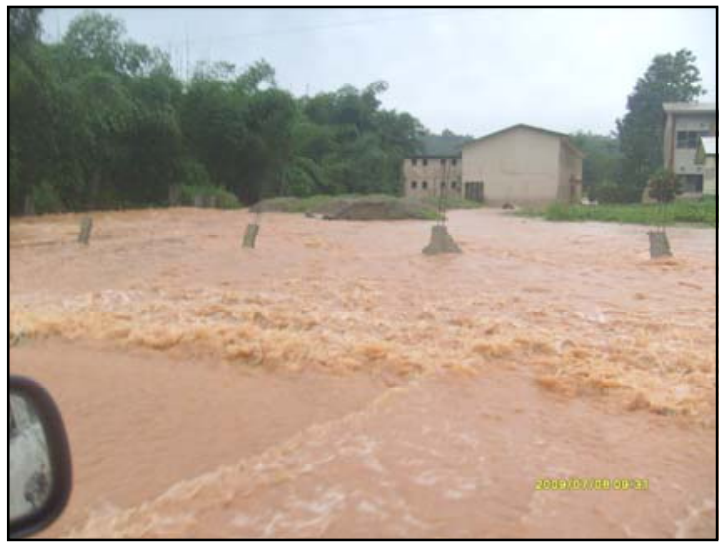

Fig. 5f Flooding of a Stream used by Illegal Miners and for Vehicle Washing during Heavy Downpour in Tarkwa 


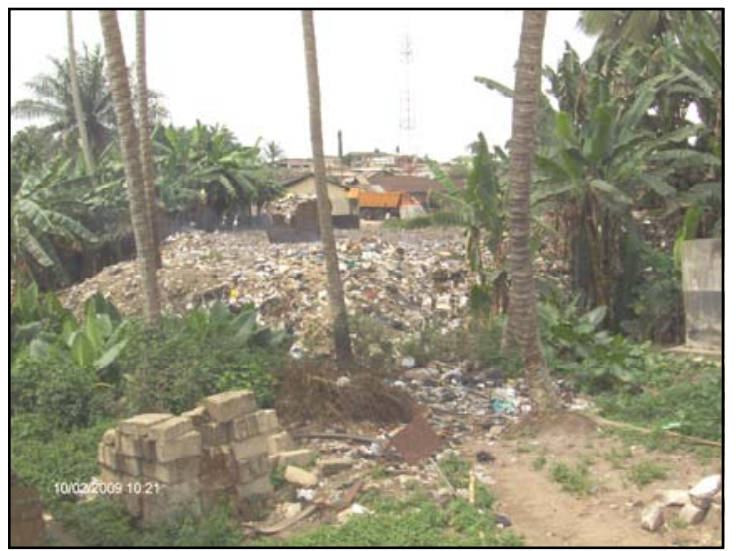

Fig. 5g Example of a Solid Waste Site which is becoming a Regular Feature in Tarkwa

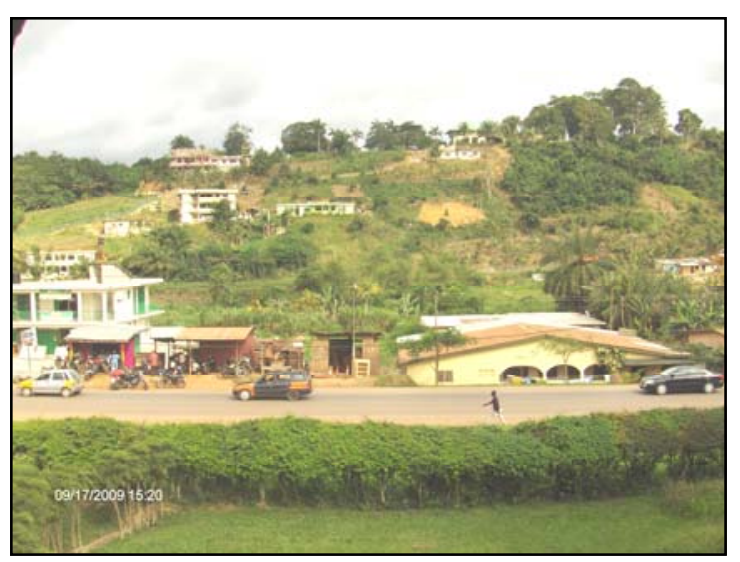

Fig. 5h Hill side Development leading to Erosion and Siltation of Streams

fessionals has resulted in high unemployment. Most of these youth have resorted to illegal gold mining with its concomitant spectacular degradation of land and water bodies leaving behind pits full of water which have become death traps in their operational areas. Some of these illegal (galamsey) mining activities are located within Tarkwa and hard rock mining has recently gained currency due to the availability of Chinese-made Chang Fa rock grinding machines. Most of the operators process their ore by washing with water near or in streams and the waste discharged into them resulting in siltation along their reaches e.g. Bediabewu, Awunabeng and Essumang streams. Siltation causes a rise of the channel floor of streams and triggers flooding during heavy down pour (Fig. 5f).

Another index of the strength of commercial activity in Tarkwa is the increase in the number of vehicular transport. For example, in 1980, less than 20 taxis were in the municipality but currently, that is, 2009, more than 350 taxis are operating in the town: more than a 15-fold increase. Consequently,
Tarkwa is one of the very few municipalities in Ghana where traffic jams are experienced. The percentage of unpaved roads in the district is about $50 \%$. As a result, most of the vehicles that ply the unpaved roads are washed regularly. This attests to the more than a dozen vehicle washing bays in Tarkwa most of which are built near streams for easy access to water, and therefore also causing significant siltation of receiving streams. During dry periods, dust pollution becomes a major problem on the unpaved roads. Feeder roads connecting the Takoradi - Tarkwa highway contribute to dust pollution in the district and this is expected to affect the quality of precipitation harvested in some households during the dry season.

In addition to water demand, population increase also brings about more solid and liquid waste generation. Disposal of these wastes is a serious issue because of its potential to contaminate surface and ground water, since there is no scientifically constructed waste disposal site in Tarkwa. However, there are several temporary solid waste sites located in the municipality and some of these are becoming regular features (Fig. $5 \mathrm{~g}$ ). Since the topography of the town is moderate, runoff is swift and wastes are easily transported into receiving tributaries e.g. the Kawere and Bediabewu. Tarkwa-Nsuaem Municipal Assembly (TNMA) has acquired permanent sites where garbage is dumped and burnt. These sites are, unfortunately, located in the catchment of the Kawere and Bonsawere tributaries that join the Bonsa River downstream. Leachate from these garbage heaps are expected to contaminate both surface and groundwater along its path. Houses have also been built in a very dense pattern and more than $70 \%$ of these have their own septic tanks. With more than 318 wells located mainly within these built-up areas, the risk of groundwater contamination is high. Liquid waste is discharged by the TNMA into dug-out pits and may become a threat in the future.

In a bid to determine whether the surface mining activities around Tarkwa have contributed to increased airbourne Particulate Matter (PM) within the township Amegbey and Ndur (2000) sampled the respirable PM below $10 \mu \mathrm{m}$ (PM 10) from 1997 to 1999 . The measured PM values ranged from $7.16 \mu \mathrm{g} / \mathrm{m}^{3}$ to $515.34 \mu \mathrm{g} / \mathrm{m}^{3}$ with $26 \%$ of the results above the limit of $70 \mu \mathrm{g} / \mathrm{m}^{3}$ set by the Environmental Protection Agency (EPA) of Ghana. The high values were generally restricted to the dry season Harmattan months between December and February. Amegbey and Ndur (2000) concluded that since untarred roads within Tarkwa are minimal, dust from mining activities are the most likely contributors to the PM concentrations measured. It is also possible to attribute part of the PM 
measured to smoke from burning garbage heaps and vehicular fumes generated within the town and all of these may affect the quality of precipitation in Tarkwa.

New housing projects being undertaken by individuals as a result of increase in population in the Tarkwa has increased significantly during the last two decades. Some of the lands are now being acquired on hill tops and slopes with problems for water quality and quantity (Fig. 5h). First, the clearing of hill tops and sides has led to the wash out of top soil, increasing runoff to and siltation of receiving surface water bodies. Secondly, most of the land acquired on the hills is on the Banket rocks which are hosts for groundwater. Recharge areas are thus used up, further reducing the groundwater recharge potential of the catchment.

\section{Management of Water Resources in the Municipality}

In Tarkwa, the Bonsa River is potentially at risk of being contaminated and will likely result in an increase in the cost of its water treatment. The GWCL in Tarkwa should plan their activities to minimise interruptions due to breakdown of its equipment or power supply so that regular water flow to homes is guaranteed. The percentage of UFW is still very high and strenuous efforts should continue to be made to reduce it and at the same time it is necessary to increase water production.

Increased use of groundwater in Tarkwa is welcome. Indeed, 179 of the wells inventoried were constructed after 2000, indicating that the need for more water has become an issue in recent years. For quality groundwater to be available to all, the TNMA would have to play a more robust role in the management of solid waste and it is recommended that engineered waste disposal facilities are built to prevent both surface and groundwater contamination from solid waste. TNMA should also educate the public with regards to the health risk arising out of the haphazard construction of water wells and the need to test and monitor their water quality periodically. Additionally, vehicle washing and small-scale mining near or into streams need TNMA's attention.

Since the gold mines are located in the best rock for storing groundwater and in recharge areas, mining activities have affected the water environment by reduction in the land area of aquifers. Under current conditions, if large-scale exploitation of groundwater is to be attempted, the most likely area to be targeted will be the Abompini catchment area (Fig. 1), which is quite far from population centres. Groundwater from this area would have to be transported about $10 \mathrm{~km}$ or more on average to where it is needed.
Water harvesting should be encouraged through community-based projects with improved mechanisms to trap and store rainwater. Secondly, with the close proximity of mines to population centres and the continuous burning of solid waste, dust suppression and better waste disposal methods need to be implemented to ensure the quality of water harvested. Regular rain water analysis is required to determine its quality.

A large void volume has been created since the beginning of mechanised underground gold mining in the early 1900s. The country rock for this ore is quartzite and the mining method employed is largely room and pillar. Since the inception of open-pit mining in 1997 by GGL, this underground mine has been abandoned and allowed to flood. GGL has maintained a partial pumping regime of the water so that surface decant at adits is prevented. This underground reservoir is a potential water resource though it is currently solely used for mineral processing. Exploitation of this water is possible because in Australia, water shortage has driven authorities into thinking of treating sewage into usable water. What requires to be done is to calculate the volume of voids created to estimate the quantity of water in store, analyse the quality with depth, determine the hydrological pathways to the underground and block the ingress of bad quality water into the reservoir. One major problem which is envisaged is the effect of old mines equipment and metals used for construction of the shaft and roadways left underground on water quality, which will require treatment before use.

Water resources management in Tarkwa must begin with a sustainable strategic plan which must take into account details of the development goals for the municipality and its environs. This plan should be initiated by the TNMA and prepared by a team of professionals comprising town planners, policy makers, environmentalists, water and health experts in the form of an environmental impact statement. Such a plan must include the delineation of groundwater protection zones and property developers must be prevented from encroaching on these zones. After its acceptance by the TNMA, a regular discussion of the document by the team should be held on the FM radio stations in town stressing the risk to public health if personal attitudinal changes are not made. This public education will help to significantly minimise some misconceptions about water availability, its use and contamination. Enforcement of the recommendations, legislation, rules and regulations of the Environmental Protection Agency (EPA), TNMA and Water Resources Commission (WRC) should then follow by deploying an oversight and monitoring personnel. 
From the above observations and discussions, although water shortage has not yet arisen in Tarkwa, it is imperative that sound water management practices are upheld so that the health of the public is guaranteed and that our actions and inactions today do not deny posterity of good quality and abundant water.

\section{Acknowledgement}

The authors are grateful to the Ghana Chamber of Mines for providing funds to undertake this study. They are also grateful to GWCL for providing some of the data used in this research. We also appreciate Mr. Sena Nani for helping us collect data on wells during the fieldwork. The views expressed in the article are however, solely those of the authors.

\section{References}

Adams, K. B., (2007), The risk of groundwater contamination from open refuse dumps, a case study at Tarkwa, southwest Ghana. Unpublished BSc. Project Report, University of Mines and Technology, Tarkwa, $42 \mathrm{pp}$.

Adusei, K., (2003), "Pricing and Tariff Design in Ghana Water Supply Sector: A case study of the Ashanti Region of Ghana”. Unpublished MSc Thesis, Department of Civil Engineering, KNUST, Kumasi, 53 pp.

Amegbey, N. and Ndur, S., (2000), “Air particulate matter monitoring in a major Ghanaian mining town - The case study of Tarkwa”. Proceedings of the sixth international conference on environmental issues and management of waste in energy and mineral production, Singhal, R. K. and Mehrotra, A. K. (Eds), SWEMP 2000, Calgary, Alberta, Canada, May 30-June 2, 2000, pp. 179-182.

Anon., (1990), Environmental Protection Agency (EPA) National Environmental Quality Standards for industrial effluents, air quality and noise levels, $13 \mathrm{pp}$.

Anon., (2000), Ghana Population and National Housing Census. Statistical Services Department of Ghana.

Antwi, N. N., (2007), Estimation of volume of water in Reservoir - A case study of Bonsa water works. Unpublished BSc. Project Report, University of Mines and Technology, Tarkwa, $13 \mathrm{pp}$.

Chang, J. H. and Lau, L. S., (1993), "Definition of the Humid Tropics". Hydrology and water management in the humid tropics: hydrological research issues and strategies for water management, Bonell, M., Hufschmidt, M. M. and Gladwell, J. S. (Eds), Cambridge University Press: pp. 571-574.
Dickson, K. B. and Benneh, G., (1995), A New Geography of Ghana. Revised Edition. Longman, England, UK, 170 pp.

Eisenlohr, B. N. and Hirdes, W., (1992), The structural development of the early Proterozoic Birimian and Tarkwaian rocks of South west Ghana, West Africa. Journal of African Earth Sciences, Vol 14, No. 3, pp. 313-325.

Hirdes, W. and Nunoo, B., (1994), The Proterozoic Paleoplacers at Tarkwa Gold Mine, SW Ghana: Sedimentology, Mineralogy and Precise Age Dating of the Main Reef and West reef, and Bearing of the Investigations on Source Area Aspects, BGR Geol Jb, D100, Hannover: pp. 247-311.

Hiscock, K. M., Rivett, M. O. and Davison, R. M., (2002), "Sustainable groundwater development”, Sustainable groundwater development, Hiscock, K. M., Rivett, M. O. and Davison, R. M. (eds) Geological Society, London, Special Publications, 193, pp. 1-14.

Junner, N. R., (1935), "Gold in the Gold Coast". Gold Coast Geological Survey, Memoir, No. 4, pp. 1-7.

Junner, N. R., Hirst, T. and Service, H., (1942), “The Tarkwa Goldfield”. Gold Coast Geological Survey, Memoir, No. 6, pp. 48-55.

Kesse, G. O., (1985), The Mineral and Rock Resources of Ghana. Balkema, Rotterdam, 615 pp.

Kortatsi, B. K., (2006), Concentration of trace metals in boreholes in the Ankobra Basin, West African Journal of Applied Ecology, Vol. 10, pp. 73-87.

Kulshreshtha, S. N., (1998), "A global outlook for water resources to the Year 2025". Water Resources Management 12, (3), pp. 167-184.

Kuma, J. S. and Younger, P. L., (2001), Pedological Characteristics Related to Ground Water Occurrence in the Tarkwa Area, Ghana. Journal of African Earth Sciences, 33, pp. 363-376.

Kuma, J. S. and Younger, P. L., (2004), Water quality trends in the Tarkwa gold mining district, Ghana. Bulletin of Engineering Geology and the Environment, 63, pp. 119-132.

Kuma, J. S., (2004), Is Groundwater in the Tarkwa Gold Mining District of Ghana Potable? International Journal of Geosciences - Environmental Geology, 45, pp. 391-400.

Kuma, J. S., (2007), Hydrogeological studies in the Tarkwa Gold Mining District, Ghana. Bulletin of Engineering Geology and the Environment 66, pp. 89 - 99.

Sraku-Lartey, K., (1993), "Production and Economic Trends in the Minerals Industry in Ghana”. Tsidzi, K. E. N. (ed.), Proceedings of the National Seminar on Current Developments in the Minerals Industry of Ghana. Kumasi, Ghana, 6-7 ${ }^{\text {th }}$ May, 1993, pp. 111-115.

Thackery, J. E., (1992), “Paying for Water; Policy 
Options and their practical Implications”, Journal of Institution Water Environment Management, Vol. 6, pp. 505-513.

Whitelaw, O. A. L., (1929), "Geological and Mining Features of the Tarkwa-Aboso Goldfield”. Gold Coast Geological Survey, Memoir No. 1, pp. 12-17.

Yepes, G. and Dianderas, A., (1996), Water and waste water utilities indicators, Second Edition, Washington D. C., Water and Sanitation Division, The World Bank, 239 pp.

\section{Authors}

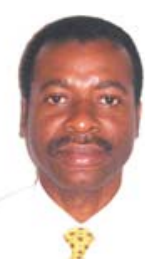

J. S. Kuma is an Associate Professor in Environmental Hydrogeology and Geophysics at the University of Mines and Technology (UMaT), Tarkwa. He was awarded a BSc (Hons) in Geology and Physics at the University of Ghana, Legon. He received the Pg Dip and MSc degrees in Geophysics at Delft, The Netherlands. Professor Kuma received a PhD in Water Resources Engineering from the University of Newcastle upon Tyne, England. He is currently actively involved in mine water hydrogeological research and water management issues.

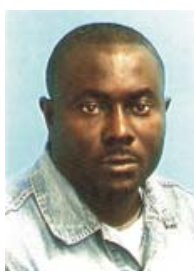

A. Ewusi holds a PhD (Groundwater Geophysics), MSc. (Environmental Resource Management) from the Brandenburg University of Technology, Germany and a BSc. (Geological Engineering) from the Kwame Nkrumah University of Science and Technology, (KNUST) Kumasi, Ghana. He has post-qualification experiences in Groundwater Exploration and Environmental Management in Germany, UK, Sierra Leone and Ghana. He has been instrumental in the application of advanced geophysical methods for groundwater exploration in Ghana. He is currently a Lecturer in Geophysics and Hydrogeology at the University of Mines and Technology (UMaT). 